\title{
Prediction of Body Weight based on Body Measurements in Crossbred Cattle
}

\author{
J. Patel Ashwini ${ }^{1 *}$, Patel Sanjay ${ }^{2}$, G.J. Amipara ${ }^{3}$, \\ P.M. Lunagariya ${ }^{4}$, D.J. Parmar ${ }^{5}$ and D.N. Rank ${ }^{6}$ \\ ${ }^{1}$ Department of Animal Genetics and Breeding, College of Veterinary Science \& Animal \\ Husbandry, ${ }^{2}$ ARDA, Amul Dairy, Anand, India \\ ${ }^{3}$ Department of Agricultural Statistics, B. A. College of Agriculture, ${ }^{4}$ Livestock Research \\ Station, College of Veterinary Science \& Animal Husbandry, ${ }^{5}$ Department of Agricultural \\ Statistics, B. A. College of Agriculture, ${ }^{6}$ Department of Animal Genetics and Breeding, \\ College of Veterinary Science \& Animal Husbandry, Anand Agricultural University, \\ Anand, India
}

*Corresponding author:

\section{A B S T R A C T}

\section{Keywords}

HF crossbred cattle, Body weight, Body length, Height at wither, Height at hip, Heart girth, Chest depth and Width of hip

\section{Article Info}

Accepted:

12 February 2019

Available Online:

10 March 2019
The study was undertaken to develop linear regression equations for prediction of body weights of HF crossbred cattle based on body measurements. The study was carried out on 506 HF crossbred cattle of Livestock Research Station, AAU, Anand; Sarsa Heifer Farm Amul Dairy, Anand; Ode Semen Station - Amul Dairy, Anand. All the data were grouped age wise. Females were grouped into 0-6 M, 6-12 M, 1-2 Y, 2-4 Y, 4-6 Y and >6 Y age groups. Simple and multiple linear regression models were formulated using step wise method using SPSS 21.0 software. Linear regression models were fitted with BW as the dependent variable and body measurements; body length (BL), height at wither (HW), height at hip (HH), heart girth (HG), chest depth (CD) and width of hip (WH) as the independent variables to obtain the relationship between BW and body measurements. High coefficient of determination values were observed in simple linear regression using $\mathrm{HG}$ alone as an independent variable in most of the age groups of HF crossbred cattle. Likewise, multiple regression equations having high coefficient of determination $\left(\mathrm{R}^{2}\right)$ value for each age groups were also developed. The present study showed that heart girth measurement can be used to predict the live body weight HF crossbred cattle age groups wise.

\section{Introduction}

Live body weight is an economic trait which helps in the selection of animals for breeding. Live body weight is one of the most important assets to harvest maximum output from milch animals. Weight of cow in proportion to its age and lactation period ensures good milk yield. Body weight of animals implies fair idea about future performance of calves and plays an important role in reproductive performance of a dairy animal and therefore, influences milk production (Kanuya et al., 2006; Roche et al., 2007). 
The overall efficiency of any cattle and buffalo breed is not only judged on the basis of milk yield, but also on the basis of their growth and development. Higher growth rate in livestock farming is not only essential for profit, but also for higher production and reproduction efficiency, better survivability and for faster genetic improvement by decreasing generation interval and increasing replacement rate (Singh et al., 2009). Body weight of animals is also associated with management practices including computing nutrient requirements, determining feeding levels and breeding of ideal heifer's weight to be mated with ideal bull's weight (Putra et al., 2014).

Therefore, the accurate estimate of live body weight is of fundamental need to any livestock research and development. But, weighing of animals is too difficult to organize or not feasible in many cases as measurement of live body weight $(\mathrm{BW})$ of large animals requires weighing scale which is heavy to transport, also need technical maintenance and too costly to buy for farmers. Hence, farmers have to rely on visual estimation of the body weight of their animals that could result into error during estimation which lead to inaccuracies in decision making.

Body measurements play significant role in evaluating breed performance and distinguish animals through predictive equations. Body measurements can be used for prediction of body weight. There is close correlation between body weight and body measurements (Ozkaya and Bozkurt, 2009). Prediction of live body weight using body measurements is practical, faster, easier and cheaper in the rural areas where the resources are insufficient for the breeder (Nsoso et al., 2003). In absence of weighing scales the widely used method to predict the weight of animals is by body measurements in which body weight is regressed on a certain number of body measurements. Different body measurements, which represent the size of the cow is one of the important criteria in selection of elite animals.

The relationship between body measurements and body weight depends upon breed, age, type, condition and fattening level of the animals (Ozkaya and Bozkurt, 2009). Formulae for body weight prediction in different indigenous breeds were developed by several workers, Ahuja et al., (1965), Dhangar and Patel (1990), Bhakat et al., (2008), Sahu et al., (2017) for Kankrej, Kankrej and Jersey halfbred calves, H.F X Tharparkar (Karan Fries) crossbred and Sahiwal cattle, respectively. But only few formulae are available for crossbred animals. Due to wide variation in body conformation of animals among the breeds a single formula for a particular breed may not justify body weight for all the crossbreds. So, there is need to generate a formula for prediction of body weight in a crossbred cattle. Therefore, the present study was undertaken to develop functional regression model to predict body weight using body measurements which represent body conformation of HF crossbred cattle.

\section{Materials and Methods}

\section{Data and its collection}

Live body weight (BW) and seven different parameters were measured on total $504 \mathrm{HF}$ crossbred cattle (male and female) from Livestock research station, College of Veterinary Science and Animal Husbandry, Anand and Amul dairy - Anand (Sarsa heifer farm - Sarsa and Ode semen station - Ode). The body measurements which were taken into consideration were body length (BL), height at wither (HW), height at hip ( $\mathrm{HH})$, heart girth (HG), chest depth (CD) and width of hip (WH). 
Farmers/animal handlers were asked to estimate animal's body weight visually in $\mathrm{kg}$ before the actual body weight of animals was measured (by digital platform balance).

\section{Statistical procedure}

Actual body weight with exact age and above measurements was collected from three different farms. All the data were assorted sex wise in male and female groups. Further female group was subdivided based on age that is 0-6 M, 6-12 M, 1-2 Y, 2-4 Y, 4-6 Y and $>6 \mathrm{Y}$. Actual body weight of an animal (which is measured on weighing scale) was considered as dependent variable and body measurements were considered as independent variables. Regression equations were developed based on stepwise method using SPSS software. Measurements which have less significant effect on model and have multicolinearity were dropped. The measurements which have highest correlation with body weight and least multicolinearity with other measurements were used to develop the best fitted functional regression model by considering adjusted coefficients of determination $\left(\mathrm{R}^{2}\right)$.

The regression model used to estimate the body weight of the cattle was

$$
Y=a+b_{1} X_{1}+b_{2} X_{2}+b_{3} X_{3}+b_{4} X_{4}+b_{5} X_{5}+b_{6} X_{6}+E
$$

The model consists of one dependent variable; $\mathrm{Y}=$ body weight, and six independent variables; $X_{1}=$ body length, $X_{2}=$ height at withers, $X_{3}=$ height at hip, $X_{4}=$ heart girth, $\mathrm{X}_{5}=$ chest depth and $\mathrm{X} 6=$ width of hip. Where, "a" is intercept, " $b$ " is regression coefficient and " $\mathrm{E}$ " is error.

For a regression equation, above formula was used in addition ofthe independent factor age (in days) inage wise pooled female and male group.

\section{Validation of regression equation}

For validation of regressions, formulae were developed using data from randomly selected $75 \%$ animals of both the sexes and validation of these formulas were done using rest $25 \%$ of data.

\section{Prediction of animal's body weight by farmer's visual estimation}

Farmers'/animal handlers' were asked to predict animal's body weight visually before actual body weight of animal was taken. The comparison of body weight predicted by animal handlers' visually to actual (recorded) BW was done by paired t-test.

\section{Results and Discussion}

The prediction equations to estimate body weight from linear body measurements using Stepwise Multiple Regression Analysis for HF crossbred female calves of 0- $6 \mathrm{M}$ age (group 1) are summarized in Table 1. Total three models were developed for this group. The regression equation of $\mathrm{BW}(\mathrm{y})$ on $\mathrm{HG}(\mathrm{x})$ for $0-6 \mathrm{M}$ of age indicated that an increase (or a decrease) of one $\mathrm{cm}$ of heart girth gave an increase (or a decrease) of $2.048 \mathrm{~kg}$ of body weight: $\mathrm{Y}=-125.157+2.048 *$ HG. The model involving $\mathrm{HG}$ showed $\mathrm{R}^{2}=0.952$ indicating that only $\mathrm{HG}$ measurement is sufficient to predict body weight reliably in female calves of birth to six months of age. Bhagat et al., (2016) observed highest $\mathrm{R}^{2}$ value in regression equations using body length (BL) in $0-6 \mathrm{M}$ Sahiwal calves. The model involving heart girth and height at wither slightly improved the efficiency of the prediction equations $\left(\mathrm{R}^{2}=0.963\right)$. The best model for estimating $\mathrm{BW}$ was model involving combination of $\mathrm{HG}, \mathrm{HW}$ and $\mathrm{CD}$, as it has the highest coefficient of determination (0.969). Dhangar and Patel (1990) predicted birth weight accurately using body length 
alone by simple regression model $\left(\mathrm{R}^{2}=\right.$ $74.72 \%$ ) and prediction accuracy increased by using $\mathrm{HG}$ and $\mathrm{HW}$ along with $\mathrm{BL}$ in multiple regression model $\left(\mathrm{R}^{2}=74.72 \%, \mathrm{R}^{2}=89.8\right.$ and $91.2 \%$ respectively).

The prediction equations to estimate body weight from linear body measurements for $\mathrm{HF}$ crossbred female calves of 6-12 $\mathrm{M}$ of age (group 2) are summarized in Table 2. Total five models were developed for this group. The model involving $\mathrm{HG}$ alone showed $\mathrm{R}^{2}=$ 0.756 value indicating that only $\mathrm{HG}$ measurement is sufficient to predict body weight of animals of this age group. In accordance of present study, Bhagat et al., (2016) found the highest $R^{2}$ value when the heart girth alone included into the regression models in 6-12 M Sahiwal calves. Bahashwan (2014) derived linear regression equation based on HG that showed excellent goodness of fit $\left(\mathrm{R}^{2}=0.915\right)$ in Dhofari calves $(1-12 \mathrm{M}$ age). The regression equation of $\mathrm{BW}$ on $\mathrm{HG}$ for live weight of animals belonging to 6-12 $M$ of age indicated that an increase (or a decrease) of one $\mathrm{cm}$ of heart girth gave an increase (or a decrease) of $2.279 \mathrm{~kg}$ of body weight: $\mathrm{Y}=-145.889+2.279 * \mathrm{HG}$. The model involving $\mathrm{HG}$ and $\mathrm{CD}$ improved the efficiency of the prediction equations $\left(\mathrm{R}^{2}=\right.$ $0.875)$. An improvement in $R^{2}$ value $(0.886)$ was seen by incorporating WH with $\mathrm{HG}$ and $\mathrm{CD}$ in model 3. Addition of $\mathrm{HH}$ with $\mathrm{HG}, \mathrm{CD}$ and $\mathrm{WH}$ gave $\mathrm{R}^{2} 0.905$ in model 4 . The body weight was obtained most accurately from the model involving the combination of $\mathrm{HG}, \mathrm{CD}$, $\mathrm{WH}, \mathrm{HH}$ and $\mathrm{HW}$ in model 5 which gave $\mathrm{R}^{2}=$ 0.918. In later models, model 4 and 5 there was only a slight improvement in $\mathrm{R}^{2}$ value (0.886 to 0.905 and 0.918 , respectively.) So, the best model for estimating $\mathrm{BW}$ with minimum measurements and efforts was model 3.

The prediction equations to estimate body weight from linear body measurements for HF crossbred heifers of 1-2 years age (group 3) are summarized in Table 3. Total three models were developed for this group. The model involving $\mathrm{HG}$ alone showed $\mathrm{R}^{2}=0.905$ indicating that only $\mathrm{HG}$ measurement is sufficient to predict body weight reliably in female calves of 1-2 years of age. The regression equation of $\mathrm{BW}(\mathrm{y})$ on $\mathrm{HG}(\mathrm{x})$ indicated that an increase (or a decrease) of one $\mathrm{cm}$ of heart girth gave an increase (or a decrease) of $4.434 \mathrm{~kg}$ of body weight: $\mathrm{Y}=$ $400.711+4.434 *$ HG. The model involving heart girth and body length improved the efficiency of the prediction equations $\left(\mathrm{R}^{2}=\right.$ 0.932). A further improvement was obtained from the model involving the combination of HG, BL and WH. So, the best model for estimating $\mathrm{BW}$ was obtained using $\mathrm{HG}, \mathrm{BL}$ and WH where both $\mathrm{R}^{2}(0.941)$ and adjusted $\mathrm{R}^{2}(0.940)$ of this model were highest.

The prediction equations to estimate body weight from linear body measurements for 2-4 years age (group 4) are summarized in Table 4. Total three models were developed for this group. The first model involving $\mathrm{HG}$ showed $\mathrm{R}^{2}=0.690$. In accordance to present study, Bhagat et al., (2016) also observed the highest $\mathrm{R}^{2}$ value when the heart girth alone included into the regression models in 2-3 Y Sahiwal female cattle. The regression equation of $\mathrm{BW}$ (y) on HG (x) for the female belonging to 2-4 years of age indicated that an increase (or a decrease) of one $\mathrm{cm}$ of heart girth gave an increase (or a decrease) of $4.173 \mathrm{~kg}$ of body weight: $\mathrm{Y}=-348.985+4.173 *$ HG. The model involving heart girth and width of hip improved the efficiency of the prediction equations $\left(\mathrm{R}^{2}=0.903\right.$ and adjusted $\mathrm{R}^{2}=$ 0.816). The last formula included three measurements $\mathrm{HG}, \mathrm{WH}$ and BL. Although last formula showed lower $\mathrm{R}^{2}$ value (0.836) compared to second formula $(0.903)$ but has higher adjusted $\mathrm{R}^{2}$ value $(0.833)$ than earlier two. As there was only a little improvement in adjusted $\mathrm{R}^{2}$ value so, second model considered 
the best for estimating BW using $\mathrm{HG}$ and $\mathrm{WH}$ for animals of this group.

The prediction equations to estimate body weight from linear body measurements for HF crossbred adult cows of 4-6 years age (group 5) are summarized in Table 5. Total two models were developed for this group. The model involving $\mathrm{HG}$ only showed $\mathrm{R}^{2}=0.765$ indicating that only $\mathrm{HG}$ measurement is sufficient to predict body weight reliably in female belonging to 4-6 years of age. The regression equation of $\mathrm{BW}(\mathrm{y})$ on $\mathrm{HG}(\mathrm{x})$ for live weight of animals ranging from 4-6 years of age indicated that an increase (or a decrease) of one $\mathrm{cm}$ of heart girth gave an increase (or a decrease) of $4.714 \mathrm{~kg}$ of body weight: $Y=-431.896+4.714 *$ HG. The model involving heart girth and body length improved the efficiency of the prediction equations $\left(\mathrm{R}^{2}=0.840\right)$ so, second model was considered as the best model for estimating $\mathrm{BW}$ using $\mathrm{HG}$ and $\mathrm{BL}$ for the cows aging 4-6 years age.

The prediction equations to estimate body weight from linear body measurements for $\mathrm{HF}$ crossbred adult cows of above 6 years age (group 6) are summarized in Table 6. Total two models were developed for this group. The model involving $\mathrm{HG}$ showed $\mathrm{R}^{2}$ value 0.402. The model involving heart girth and width of hip improved the efficiency of the prediction equations $\left(\mathrm{R}^{2}=0.528\right)$. So, second model was considered as the best model to estimate body weight of cows belonging this age group. In this model $\mathrm{R}^{2}$ and adjusted $\mathrm{R}^{2}$ value were not so good as this group was heterogeneous with wide range of age so, accuracy of formula got less compared to other groups.

Prediction equations for female (pooled over age group, including age as a factor) was developed using $75 \%$ randomly choose data (324 females). Here, BW showed the highest correlation with $\mathrm{WH}(0.965)$ followed by HG(0.961), CD(0.937), BL(0.933), HH (0.907), HW(0.904) and age(0.826).The prediction equations to estimate body weight summarized in Table 7. Total three models were developed for this group. The first model involving width of hip only showed $\mathrm{R}^{2}=$ 0.930 value. The regression equation of $\mathrm{BW}$ (y) on WH (x) for HF crossbred female cattle indicated that an increase (or a decrease) of one $\mathrm{cm}$ of width of hip gave an increase (or a decrease) of $13.24 \mathrm{~kg}$ of body weight: $\mathrm{Y}=$ $237.347+4.173 *$ WH. The model involving width of hip with age in days improved the efficiency of the prediction equations $\left(\mathrm{R}^{2}=\right.$ 0.948). The last model was developed by the combination of $\mathrm{WH}$, Age and $\mathrm{HG}$ showing improvement in $\mathrm{R}^{2}$ value (0.961). So, model 3 was considered as the best model for estimating BW for females of all age group. All prediction models of this group derived from the present study indicated that width of hip is the most important measurement for prediction of live weight.

Prediction equations for female (pooled over age groups, excluding age as a factor) was developed using $75 \%$ randomly choose data (324 females). The objective of developing formula excluding age was, if farmer didn't know the age of his animal then too he can predict the body weight accurately. WH showed the highest correlation (0.964) with body weight followed by HG (0.956), CD (0.937), BL (0.928), HH (0.904) and HW (0.903). The prediction equations to estimate body weight from linear body measurements for HF crossbred female cattle (pooled over age groups, without age factor) are summarized in Table 8. Total four models were developed for this group. The model involving width of hip and heart girth improved the efficiency of the prediction equations $\left(\mathrm{R}^{2}=0.944\right)$. Bhakat et al., (2008) reported 61.57 and $52.28 \mathrm{R}^{2}$ value using $\mathrm{HG}$ alone in Karan Fries cattle and Murrah 
buffalo, respectively. Several workers previously studied different breeds and concluded that the weights could be predicted precisely using heart girth only [Tuzeman et al., (1995); Putra et al., (2014); Kashoma et al., (2011); Milla et al., (2012); Paul and Das (2012); El-Hedainy et al., (2013); Katongole et al., (2013) and Siddiqui et al., (2015)]. The $\mathrm{R}^{2}$ value based on the HG model in several cattle breeds were generally high as reported by Nesamvuni et al., (2000); Goe et al., (2001); Serkan and Yalcin (2009), Alsiddig et al., (2010) and Sawanon et al., (2011). Existence of a significant linear relationship between BW and HG were reported by Msangi et al., (1999) in crossbred dairy cattle and Abdelhadi and Babiker (2012) in Baggara zebu. Putra et al., (2014) reported that the accuracy of estimation could be improved if the variables were combined in a multiple regression. Same author also noted $\mathrm{WH}, \mathrm{BL}$ and $\mathrm{HG}$ were the important body measurements required for predicting the $\mathrm{BW}$ in Aceh cattle. Estimated BW in Aceh cattle using $\mathrm{WH}, \mathrm{BL}$ and $\mathrm{HG}$ as independent variables in multiple regression produced the highest accuracies of BW prediction among all Aceh cattle (both sex groups). Total four models were developed, progressively adding independent traits $(\mathrm{CD}$ and $\mathrm{WH}$ : Model 3, and addition of HH: model 4) But model 3 and 4 didn't add much to the improvement of $\mathrm{R}^{2}$ value. So it's better to use model 2 instead model 3 or 4. Bhakat et al., (2008) reported the highest $\mathrm{R}^{2}$ value of $(72.24 \%)$ and $(66.90$ $\%)$ using multiple linear regression equation in Karan Fries cattle and Murrah buffalo, respectively. Bozkurt (2006) reported $\mathrm{R}^{2}$ values $94.00 \%$ from the equation that contained HW, BL and HG in Brown Swiss cattle. Tuzemen et al., (1995) and Ulutas et al., (2002) also reported high $\mathrm{R}^{2}$ value from the multiple regression equation. Tasdemir $e t$ al., (2011) reported the highest $\mathrm{R}^{2}$ value (97.9 $\%$ ) by using $\mathrm{WH}, \mathrm{HH}, \mathrm{BL}$ and $\mathrm{HW}$ in linear multi regression equation.
Validation of final model of female $\mathrm{HF}$ crossbred cattle

In $\mathrm{HF}$ crossbred female group (pooled over age groups) model $3(\mathrm{Y}=-247.101+6.059 *$ $\mathrm{WH}+0.032 * \mathrm{AGE}+1.731 * \mathrm{HG}$ ) showing 0.961 accuracy, was used to validate on rest $25 \%$ of HF crossbred female animals. The mean of actual (recorded) body weights was $272.536 \pm 12.165 \mathrm{~kg}$, while predicted mean body weight by above model was $272.495 \pm$ $11.626 \mathrm{~kg}$. There was a positive and highly significant correlation between actual and predicted body weights $\left(0.986^{* *}\right)$ and there was non significant difference between actual and predicted body weights by above model as tested by $t$ test $(0.985, p<0.05)$. A line diagram showing actual and predicted body weight using model for this group is given in Figure 1.

Same way, validation of final formula which was developed excluding age factor was done. Total four models that were developed by progressively adding independent traits one by one but model $2(\mathrm{Y}=$ $301.142+7.998 * \mathrm{WH}+1.796 * \mathrm{HG})$, onwards not much gain in $\mathrm{R}^{2}$ value was observed so, model 2 was used for validation on rest $25 \%$ of HF crossbred female animals. Here, actual mean body weight was $272.536 \pm 12.1651 \mathrm{~kg}$ while mean body weight by model 2 was $273.819 \pm$ $11.52354 \mathrm{~kg}$. There was a positive and highly significant correlation $(0.979 * *)$ between these two and there was a nonsignificant difference between actual and predicted by above model as tested by $\mathrm{t}$ test $(0.608$, $\mathrm{p}<0.05$ ). A line diagram showing actual and predicted body weight using model for this group is given in Figure 2.

Several earlier studies described validation of prediction models in different breeds. Linear regression equation derived by Bahashwan (2014) based on HG showed excellent goodness of fit $\left(\mathrm{R}^{2}=0.915\right)$ with to actual 
body weight. There was a nonsignificant difference $(\mathrm{P}>0.05)$ between actual live body weight and model derived live weight in Dhofari calves (1- $12 \mathrm{M}$ age). Yan et al., (2009) evaluated equations through internal validation, by developing a range of similar new equations to predict body weight using body size measurements in HF lactating dairy cows from two thirds of the data and then validating these new equations with the remaining one third of data. They concluded that body measurements can be used together with other live animal factors to accurately predict body weight and estimated body component mass of lactating dairy cows. Sawanon et al., (2011) developed models for feed lot cattle and grass- fed cattle with 90 and $87 \%$ accuracy. They showed nonsignificant $(\mathrm{P}=0.99$ ) difference (with means of live body weight of feedlot and grass-fed) between actual live body weight and live body weight predicted with the equations in their study.

\section{Correlation between actual and farmer's predicted body weight}

Farmers' / animal handlers' were asked to predict body weight visually before actual body weight of an animal was taken by electric weighing balance. The mean of farmers' predicted and actual body weight are depicted in table 9. The predicted mean body weight in different age groups were $61.800 \pm$ $6.145 \mathrm{~kg}, 90.106 \pm 3.943 \mathrm{~kg}, 212.256 \pm 7.123$ $\mathrm{kg}, 318.566 \pm 5.633 \mathrm{~kg}, 427.973 \pm 12.042 \mathrm{~kg}$, $447.368 \pm 9.181 \mathrm{~kg}$ while actual mean body weight were $66.365 \pm 5.709 \mathrm{~kg}, 117.840 \pm$ $2.981 \mathrm{~kg}, 229.477 \pm 5.369 \mathrm{~kg}, 318.249 \pm$ $3.763 \mathrm{~kg}, 407.702 \pm 11.105 \mathrm{~kg}$ and $479.418 \pm$ $7.838 \mathrm{~kg}$ in age groups $1,2,3,4,5$ and 6 , respectively.

Animal handlers' visual estimated body weight and actual body weight group wise as well as pooled over age groups was tested by paired t test data as depicted in Table 9. There was a significant difference observed between farmers' predicted and actual body weight in most of the age groups indicating that farmers / animal handlers couldn't predict actual body weight visually. Only in case of the group 4 (2 - 4 Y) females differences between predicted and actual body weight were nonsignificant suggesting that farmers could predict body weight visually. When handler asked to predict body weight very first animal he predicted as per their views unbiasely and then animal was weighted by electric machine.

Table.1 Regression models for the prediction of live body weight from linear body measurements in HF crossbred female group 1 (0-6 M age)

\begin{tabular}{|c|c|c|c|c|c|c|c|c|}
\hline \multirow[t]{2}{*}{$\mathbf{M}$} & \multirow[t]{2}{*}{ Variables } & \multicolumn{3}{|c|}{ Coefficients } & \multirow[t]{2}{*}{ (t) } & \multirow[t]{2}{*}{ Sig. } & \multirow[t]{2}{*}{$\mathbf{R}^{2}$} & \multirow[t]{2}{*}{ Adj.: ${ }^{2}$} \\
\hline & & (a) & (b) & S.E & & & & \\
\hline \multirow[t]{2}{*}{1} & constant & -125.157 & - & 7.128 & -17.55 & 0.000 & \multirow[t]{2}{*}{0.952} & \multirow[t]{2}{*}{0.950} \\
\hline & $\mathrm{HG}$ & - & 2.048 & 0.075 & 27.30 & 0.000 & & \\
\hline \multirow[t]{3}{*}{2} & constant & -150.757 & - & 9.758 & -15.44 & 0.000 & \multirow[t]{3}{*}{0.963} & \multirow[t]{3}{*}{0.961} \\
\hline & HG & - & 1.330 & 0.219 & 06.06 & 0.000 & & \\
\hline & HW & - & 1.122 & 0.327 & 03.43 & 0.001 & & \\
\hline \multirow[t]{4}{*}{3} & constant & -145.014 & - & 8.930 & -16.23 & 0.000 & \multirow[t]{4}{*}{0.971} & \multirow[t]{4}{*}{0.969} \\
\hline & $\mathrm{HG}$ & & 0.864 & 0.245 & 03.52 & 0.001 & & \\
\hline & HW & & 0.979 & 0.297 & 03.30 & 0.002 & & \\
\hline & $\mathrm{CD}$ & & 1.370 & 0.432 & 03.17 & 0.003 & & \\
\hline
\end{tabular}

$\left(\mathrm{M}=\right.$ Model, $\mathrm{a}=$ Intercept and $\mathrm{b}=$ Regression coefficients, $\mathrm{Adj} . \mathrm{R}^{2}=$ adjusted $\left.\mathrm{R}^{2}\right)$ 
Table.2 Regression models for the prediction of live body weight from linear body measurements in HF crossbred female group 2 (6-12 M)

\begin{tabular}{|c|c|c|c|c|c|c|c|c|}
\hline \multirow[t]{2}{*}{ M } & \multirow[t]{2}{*}{ Variables } & \multicolumn{3}{|c|}{ Coefficients } & \multirow[t]{2}{*}{ (t) } & \multirow[t]{2}{*}{ Sig. } & \multirow[t]{2}{*}{$\mathbf{R}^{2}$} & \multirow{2}{*}{$\begin{array}{l}\text { Adj. } \\
\mathbf{R}^{2}\end{array}$} \\
\hline & & (a) & (b) & SE & & & & \\
\hline \multirow[t]{2}{*}{1} & Constant & -145.889 & - & 22.371 & -6.52 & 0.000 & \multirow[t]{2}{*}{0.756} & \multirow[t]{2}{*}{0.751} \\
\hline & HG & - & 2.279 & 00.193 & 11.81 & 0.000 & & \\
\hline \multirow[t]{3}{*}{2} & Constant & -192.774 & - & 17.752 & -10.85 & 0.000 & \multirow[t]{3}{*}{0.875} & \multirow[t]{3}{*}{0.869} \\
\hline & HG & & 1.720 & 00.164 & 10.46 & 0.000 & & \\
\hline & CD & & 2.532 & 00.392 & 06.46 & 0.000 & & \\
\hline \multirow[t]{4}{*}{3} & Constant & -176.300 & - & 17.628 & -10.00 & 0.000 & \multirow[t]{4}{*}{0.894} & \multirow[t]{4}{*}{0.886} \\
\hline & HG & & 1.397 & 00.194 & 07.21 & 0.000 & & \\
\hline & CD & & 2.055 & 00.405 & 05.07 & 0.000 & & \\
\hline & WH & & 1.543 & 00.563 & 02.73 & 0.009 & & \\
\hline \multirow[t]{5}{*}{4} & Constant & -183.352 & - & 17.179 & -10.67 & 0.000 & \multirow{5}{*}{0.905} & \multirow[t]{5}{*}{0.896} \\
\hline & HG & & 1.162 & 00.214 & 05.44 & 0.000 & & \\
\hline & CD & & 1.749 & 00.412 & 04.25 & 0.000 & & \\
\hline & WH & & 1.643 & 00.541 & 03.03 & 0.004 & & \\
\hline & $\mathrm{HH}$ & & 0.432 & 00.195 & 02.21 & 0.032 & & \\
\hline \multirow[t]{6}{*}{5} & Constant & -170.346 & - & 16.864 & -10.10 & 0.000 & \multirow[t]{6}{*}{0.918} & \multirow[t]{6}{*}{0.908} \\
\hline & HG & & 1.479 & 00.234 & 06.31 & 0.000 & & \\
\hline & CD & & 2.178 & 00.420 & 05.19 & 0.000 & & \\
\hline & WH & & 1.255 & 00.529 & 02.37 & 0.022 & & \\
\hline & $\mathrm{HH}$ & & 0.703 & 00.211 & 03.33 & 0.002 & & \\
\hline & HW & & -0.889 & 00.341 & -2.60 & 0.013 & & \\
\hline
\end{tabular}

$\left(\mathrm{M}=\right.$ Model, $\mathrm{a}=$ Intercept and $\mathrm{b}=$ Regression coefficients, Adj. $\mathrm{R}^{2}=$ adjusted $\left.\mathrm{R}^{2}\right)$

Table.3 Regression models for the prediction of live body weight from linear body measurements in HF crossbred female group 3 (1-2Y)

\begin{tabular}{|c|c|c|c|c|c|c|c|c|}
\hline \multirow[t]{2}{*}{ M } & \multirow[t]{2}{*}{ variables } & \multicolumn{3}{|c|}{ Coefficients } & \multirow[t]{2}{*}{ (t) } & \multirow[t]{2}{*}{ Sig. } & \multirow[t]{2}{*}{$\mathbf{R}^{2}$} & \multirow{2}{*}{$\begin{array}{l}\text { Adj. } \\
\mathbf{R}^{2}\end{array}$} \\
\hline & & (a) & (b) & SE & & & & \\
\hline \multirow[t]{2}{*}{1} & Constant & -400.711 & & 19.48 & -20.57 & 0.000 & \multirow[t]{2}{*}{0.905} & \multirow[t]{2}{*}{0.904} \\
\hline & HG & & 4.434 & 00.13 & 32.47 & 0.000 & & \\
\hline \multirow[t]{3}{*}{2} & Constant & -413.193 & & 16.60 & -24.80 & 0.000 & \multirow[t]{3}{*}{0.932} & \multirow[t]{3}{*}{0.931} \\
\hline & HG & & 2.859 & 00.26 & 10.89 & 0.000 & & \\
\hline & $\mathrm{BL}$ & & 1.858 & 00.27 & 06.68 & 0.000 & & \\
\hline \multirow[t]{4}{*}{3} & Constant & -385.773 & & 16.90 & -22.81 & 0.000 & \multirow[t]{4}{*}{0.941} & \multirow[t]{4}{*}{0.940} \\
\hline & HG & & 2.428 & 00.26 & 09.09 & 0.000 & & \\
\hline & $\mathrm{BL}$ & & 1.385 & 00.28 & 04.87 & 0.000 & & \\
\hline & WH & & 2.614 & 00.63 & 04.09 & 0.000 & & \\
\hline
\end{tabular}

$\left(\mathrm{M}=\right.$ Model, $\mathrm{a}=$ Intercept and $\mathrm{b}=$ Regression coefficients, Adj. $\mathrm{R}^{2}=$ adjusted $\left.\mathrm{R}^{2}\right)$ 
Table.4 Regression models for the prediction of live body weight from linear body measurements of HF crossbred female group 4 (2-4 Y)

\begin{tabular}{|c|c|c|c|c|c|c|c|c|}
\hline \multirow[t]{2}{*}{$\mathbf{M}$} & \multirow[t]{2}{*}{ Variables } & \multicolumn{3}{|c|}{ Coefficients } & \multirow[t]{2}{*}{ (t) } & \multirow[t]{2}{*}{ Sig. } & \multirow[t]{2}{*}{$\mathbf{R}^{2}$} & \multirow[t]{2}{*}{ Adj. $R^{2}$} \\
\hline & & (a) & (b) & SE & & & & \\
\hline \multirow[t]{2}{*}{1} & Constant & -348.98 & & 35.80 & -09.74 & 0.000 & \multirow[t]{2}{*}{0.692} & \multirow[t]{2}{*}{0.690} \\
\hline & $\mathrm{HG}$ & & 04.17 & 00.22 & 18.67 & 0.000 & & \\
\hline \multirow[t]{3}{*}{2} & Constant & -373.83 & & 27.87 & -13.41 & 0.000 & \multirow[t]{3}{*}{0.903} & \multirow[t]{3}{*}{0.816} \\
\hline & $\mathrm{HG}$ & & 2.476 & 00.24 & 10.29 & 0.000 & & \\
\hline & WH & & 6.984 & 00.68 & 10.17 & 0.000 & & \\
\hline \multirow[t]{4}{*}{3} & Constant & -416.57 & & 28.13 & -14.80 & 0.000 & \multirow[t]{4}{*}{0.836} & \multirow[t]{4}{*}{0.833} \\
\hline & $\mathrm{HG}$ & & 2.248 & 00.23 & 09.63 & 0.000 & & \\
\hline & WH & & 5.422 & 00.74 & 07.31 & 0.000 & & \\
\hline & $\mathrm{BL}$ & & 1.020 & 00.23 & 04.36 & 0.000 & & \\
\hline
\end{tabular}

$\left(\mathrm{M}=\right.$ Model, $\mathrm{a}=$ Intercept and $\mathrm{b}=$ Regression coefficients, Adj. $\mathrm{R}^{2}=$ adjusted $\left.\mathrm{R}^{2}\right)$

Table.5 Regression models for the prediction of live body weight from linear body measurements in HF crossbred female group 5 (4-6 Y)

\begin{tabular}{|c|c|c|c|c|c|c|c|c|}
\hline \multirow[t]{2}{*}{ M } & \multirow[t]{2}{*}{ Variables } & \multicolumn{3}{|c|}{ Coefficients } & \multirow[t]{2}{*}{$\mathbf{T}$} & \multirow[t]{2}{*}{ Sig. } & \multirow[t]{2}{*}{$\mathbf{R}^{2}$} & \multirow[t]{2}{*}{ Adj. $\mathbf{R}^{2}$} \\
\hline & & (a) & (b) & SE & & & & \\
\hline \multirow[t]{2}{*}{1} & Constant & -431.896 & & 78.95 & -5.47 & 0.000 & \multirow[t]{2}{*}{0.765} & \multirow[t]{2}{*}{0.758} \\
\hline & $\mathrm{HG}$ & & 4.714 & 00.44 & 10.66 & 0.000 & & \\
\hline \multirow[t]{3}{*}{2} & Constant & -687.807 & & 91.86 & -7.48 & 0.000 & \multirow[t]{3}{*}{0.840} & \multirow[t]{3}{*}{0.831} \\
\hline & $\mathrm{HG}$ & & 4.243 & 00.38 & 10.93 & 0.000 & & \\
\hline & $\mathrm{BL}$ & & 2.241 & 00.55 & 04.00 & 0.000 & & \\
\hline
\end{tabular}

$\left(\mathrm{M}=\right.$ Model, $\mathrm{a}=$ Intercept and $\mathrm{b}=$ Regression coefficients, Adj. $\left.\mathrm{R}^{2}=\operatorname{adjusted} \mathrm{R}^{2}\right)$

Table.6 Regression models for the prediction of live body weight from linear body measurements in HF crossbred cattle group 6 ( $>6 \mathrm{Y}$ age)

\begin{tabular}{|c|c|c|c|c|c|c|c|c|}
\hline \multirow[t]{2}{*}{$\mathbf{M}$} & \multirow[t]{2}{*}{ Variables } & \multicolumn{3}{|c|}{ Coefficients } & \multirow[t]{2}{*}{ (t) } & \multirow[t]{2}{*}{ Sig. } & \multirow[t]{2}{*}{$\mathbf{R}^{2}$} & \multirow{2}{*}{$\underset{\mathbf{R}^{2}}{\text { Adj. }}$} \\
\hline & & (a) & (b) & SE & & & & \\
\hline \multirow[t]{2}{*}{1} & Constant & -071.856 & & 112.16 & -0.641 & 0.526 & \multirow[t]{2}{*}{0.402} & \multirow[t]{2}{*}{0.386} \\
\hline & HG & & 3.009 & 000.61 & 4.922 & 0.000 & & \\
\hline \multirow[t]{3}{*}{2} & Constant & -217.079 & & 111.75 & -1.943 & 0.060 & \multirow[t]{3}{*}{0.528} & \multirow[t]{3}{*}{0.501} \\
\hline & HG & & 2.095 & 000.63 & 3.340 & 0.002 & & \\
\hline & WH & & 6.111 & 002.00 & 3.051 & 0.004 & & \\
\hline
\end{tabular}


Table.7 Regression models for the prediction of live body weight from linear body measurements in HF crossbred cattle (pooled over age groups) (including age as a factor)

\begin{tabular}{|c|c|c|c|c|c|c|c|c|}
\hline \multirow{3}{*}{$\mathbf{N}$} & \multirow{3}{*}{ Variables } & & & & & & & $n=324$ \\
\hline & & \multicolumn{3}{|c|}{ Coefficients } & \multirow[t]{2}{*}{$\mathbf{T}$} & \multirow[t]{2}{*}{ Sig. } & \multirow[t]{2}{*}{$\mathbf{R}^{2}$} & \multirow{2}{*}{$\underset{\mathbf{R}^{2}}{\text { Adj. }}$} \\
\hline & & (a) & (b) & SE & & & & \\
\hline \multirow[t]{2}{*}{1} & Constant & -237.347 & & 7.979 & -29.748 & 0.000 & \multirow[t]{2}{*}{0.930} & \multirow[t]{2}{*}{0.930} \\
\hline & WH & & 13.244 & 0.202 & 65.513 & 0.000 & & \\
\hline \multirow[t]{3}{*}{2} & Constant & -184.171 & & 8.523 & -21.610 & 0.000 & \multirow[t]{3}{*}{0.948} & \multirow[t]{3}{*}{0.948} \\
\hline & WH & & 11.056 & 0.271 & 40.867 & 0.000 & & \\
\hline & AGE & & 00.033 & 0.003 & 10.576 & 0.000 & & \\
\hline \multirow[t]{4}{*}{3} & Constant & -247.101 & & 9.656 & -25.590 & 0.000 & \multirow[t]{4}{*}{0.961} & \multirow[t]{4}{*}{0.961} \\
\hline & WH & & 06.059 & 0.544 & 11.130 & 0.000 & & \\
\hline & AGE & & 00.032 & 0.003 & 11.815 & 0.000 & & \\
\hline & HG & & 01.731 & 0.170 & 10.181 & 0.000 & & \\
\hline
\end{tabular}

$\left(\mathrm{M}=\right.$ Model, $\mathrm{a}=$ Intercept and $\mathrm{b}=$ Regression coefficients, $\left.\mathrm{Adj} . \mathrm{R}^{2}=\operatorname{adjusted} \mathrm{R}^{2}\right)$

Table.8 Regression models for the prediction of live body weight from linear body measurements in HF crossbred female (pooled over age groups, excluding age as a factor)

\begin{tabular}{|c|c|c|c|c|c|c|c|c|}
\hline \multirow{3}{*}{ M } & \multirow{3}{*}{ Variables } & \multirow{2}{*}{\multicolumn{3}{|c|}{ Coefficients }} & \multirow{3}{*}{$\mathbf{T}$} & \multirow{3}{*}{ Sig. } & \multirow{3}{*}{$\mathbf{R}^{2}$} & $n=324$ \\
\hline & & & & & & & & \multirow{2}{*}{$\begin{array}{c}\text { Adj. } \\
\mathbf{R}^{2}\end{array}$} \\
\hline & & (a) & (b) & SE & & & & \\
\hline \multirow[t]{2}{*}{1} & Constant & -237.347 & & 07.979 & -29.748 & 0.000 & \multirow[t]{2}{*}{0.930} & \multirow[t]{2}{*}{0.930} \\
\hline & WH & & 13.244 & 00.202 & 65.513 & 0.000 & & \\
\hline \multirow[t]{3}{*}{2} & Constant & -301.142 & & 10.176 & -29.593 & 0.000 & \multirow[t]{3}{*}{0.944} & \multirow[t]{3}{*}{0.944} \\
\hline & WH & & 07.998 & 00.621 & 12.878 & 0.000 & & \\
\hline & HG & & 01.796 & 00.203 & 8.832 & 0.000 & & \\
\hline \multirow[t]{4}{*}{3} & Constant & -306.134 & & 10.328 & -29.640 & 0.000 & \multirow[t]{4}{*}{0.945} & \multirow[t]{4}{*}{0.944} \\
\hline & WH & & 07.478 & 00.656 & 11.406 & 0.000 & & \\
\hline & HG & & 01.506 & 00.237 & 6.354 & 0.000 & & \\
\hline & CD & & 01.202 & 00.514 & 2.341 & 0.020 & & \\
\hline \multirow[t]{5}{*}{4} & Constant & -273.830 & & 16.901 & -16.202 & 0.000 & \multirow[t]{5}{*}{0.946} & \multirow[t]{5}{*}{0.945} \\
\hline & WH & & 07.550 & 00.651 & 11.589 & 0.000 & & \\
\hline & HG & & 01.788 & 00.263 & 6.801 & 0.000 & & \\
\hline & $\mathrm{CD}$ & & 01.521 & 00.527 & 2.887 & 0.004 & & \\
\hline & $\mathrm{HH}$ & & -0.788 & 00.328 & -2.404 & 0.017 & & \\
\hline
\end{tabular}

$\left(\mathrm{M}=\right.$ Model, $\mathrm{a}=$ Intercept and $\mathrm{b}=$ Regression coefficients, Adj. $\mathrm{R}^{2}=\operatorname{adjusted} \mathrm{R}^{2}$ ) 
Table.9 Comparison of visually predicted body weight by farmers and actual mean body weight of HF crossbred cattle

\begin{tabular}{|c|c|c|c|c|c|c|c|c|c|c|}
\hline & Gro & & $\mathbf{N}$ & Mean & S.E mean & Mean & S.E diff. & $\mathbf{t}$ & df & Sig. \\
\hline \multirow[t]{12}{*}{ Female } & \multirow[t]{2}{*}{ Group 1} & $\begin{array}{l}\text { PB } \\
W\end{array}$ & 040 & 061.800 & 06.145 & \multirow[t]{2}{*}{-04.565} & \multirow[t]{2}{*}{01.452} & \multirow[t]{2}{*}{-03.142} & \multirow[t]{2}{*}{039} & \multirow[t]{2}{*}{0.003} \\
\hline & & BW & 040 & 066.365 & 05.709 & & & & & \\
\hline & \multirow[t]{2}{*}{ Group 2} & $\begin{array}{l}\mathrm{PB} \\
\mathrm{W}\end{array}$ & 047 & 090.106 & 03.943 & \multirow[t]{2}{*}{-27.734} & \multirow[t]{2}{*}{02.189} & \multirow[t]{2}{*}{-12.665} & \multirow[t]{2}{*}{046} & \multirow[t]{2}{*}{0.000} \\
\hline & & BW & 047 & 117.840 & 02.981 & & & & & \\
\hline & \multirow[t]{2}{*}{ Group 3} & $\begin{array}{l}\mathrm{PB} \\
\mathrm{W}\end{array}$ & 113 & 212.256 & 07.123 & \multirow[t]{2}{*}{-17.221} & \multirow[t]{2}{*}{04.057} & \multirow[t]{2}{*}{-04.244} & \multirow[t]{2}{*}{112} & \multirow[t]{2}{*}{0.000} \\
\hline & & BW & 113 & 229.477 & 05.369 & & & & & \\
\hline & \multirow[t]{2}{*}{ Group 4} & $\begin{array}{l}\text { PB } \\
W\end{array}$ & 157 & 318.566 & 05.633 & \multirow[t]{2}{*}{00.317} & \multirow[t]{2}{*}{04.368} & \multirow[t]{2}{*}{00.073} & \multirow[t]{2}{*}{156} & \multirow[t]{2}{*}{0.942} \\
\hline & & BW & 157 & 318.249 & 03.763 & & & & & \\
\hline & \multirow[t]{2}{*}{ Group 5} & $\begin{array}{l}\mathrm{PB} \\
\mathrm{W}\end{array}$ & 037 & 427.973 & 12.042 & \multirow[t]{2}{*}{20.270} & \multirow[t]{2}{*}{06.234} & \multirow[t]{2}{*}{03.251} & \multirow[t]{2}{*}{036} & \multirow[t]{2}{*}{0.002} \\
\hline & & BW & 037 & 407.702 & 11.105 & & & & & \\
\hline & \multirow[t]{2}{*}{ Group 6} & $\begin{array}{l}\text { PB } \\
W\end{array}$ & 038 & 447.368 & 09.181 & \multirow[t]{2}{*}{-32.050} & \multirow[t]{2}{*}{09.535} & \multirow[t]{2}{*}{-03.361} & \multirow[t]{2}{*}{037} & 0.002 \\
\hline & & BW & 038 & 479.418 & 07.838 & & & & & \\
\hline $\begin{array}{l}\text { Female } \\
\text { (pooled over }\end{array}$ & Whole & $\begin{array}{l}\text { PB } \\
W\end{array}$ & 432 & 262.828 & 06.523 & -08.912 & 02.270 & -03.926 & 431 & 0.000 \\
\hline age groups) & & BW & 432 & 271.741 & 05.997 & & & & & \\
\hline
\end{tabular}


Fig.1 Line diagram (on $\mathrm{X}$ axis animals and $\mathrm{Y}$ axis body weight) showing actual and predicted body weight by model (including age factor) in pooled HF crossbred female $(n=108)$

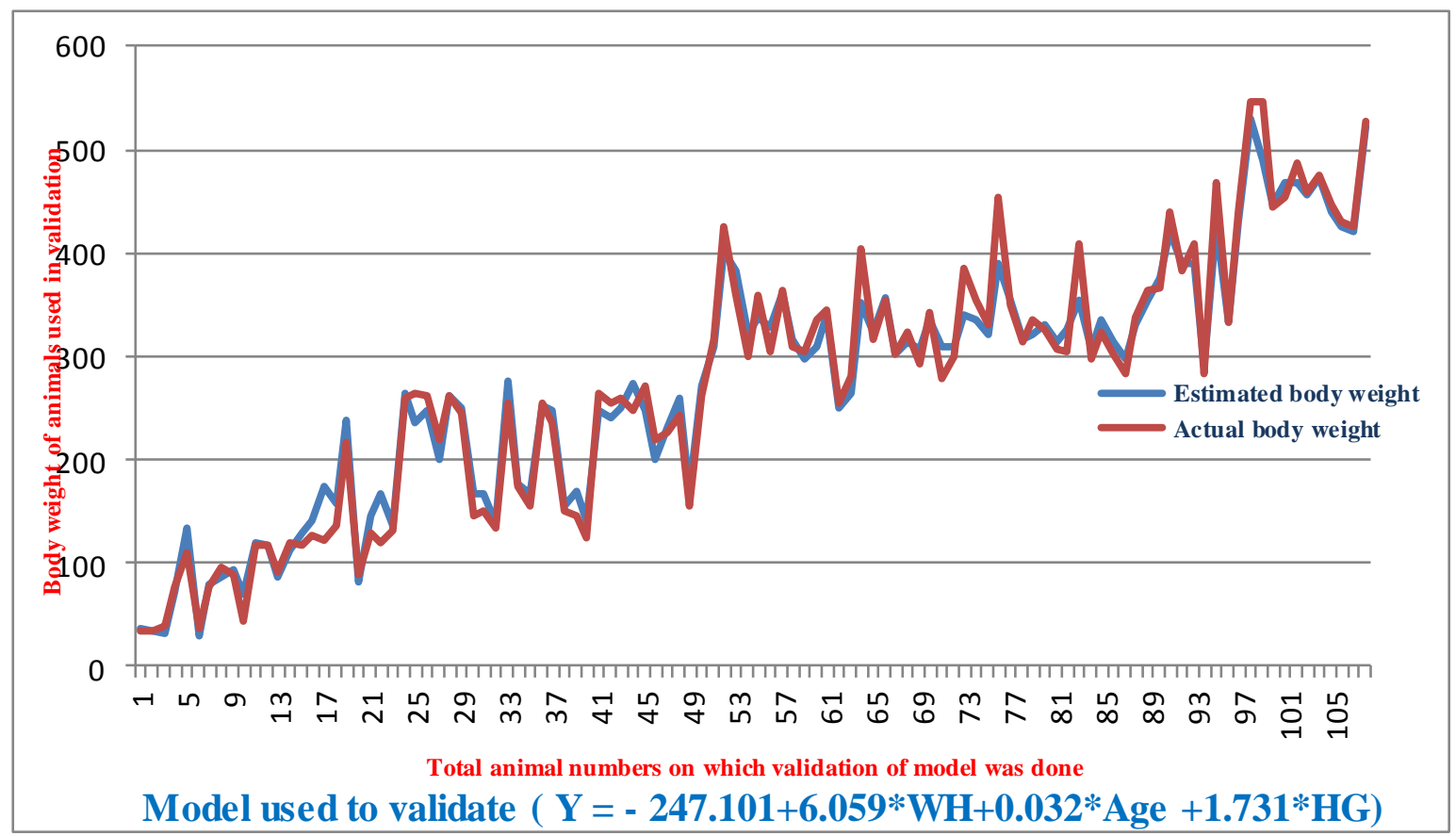

Fig.2 Line diagram (on $\mathrm{X}$ axis animals and $\mathrm{Y}$ axis body weight) showing actual and predicted body weight by model (excluding age factor) in HF crossbred female pooled group $(\mathrm{n}=108)$

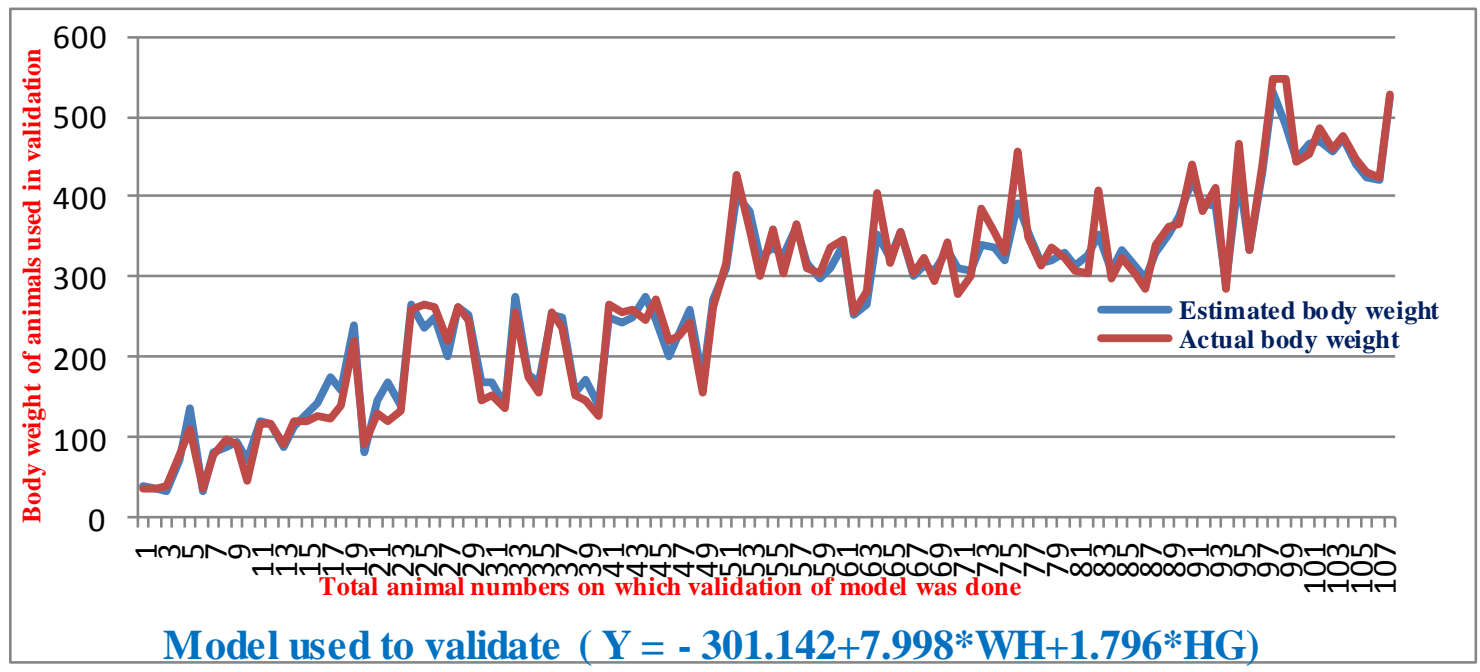

When the same person was again asked to predict body weight of next animal he tried to predict body weight as per previous animal's actual body weight. This would make their prediction biased in judging the weight. This would give impression that predicted body weight is reliable however in real sense it is not.

In conclusion, the aim of this study was to provide farmers with a simple and reliable tool for estimating the BW in HF crossbred 
cattle. Age group wise simple regression equations with high coefficient of determination values $\left(\mathrm{R}^{2}\right)$ could also be developed using heart girth as an independent trait. Likewise, multiple regression equations having high coefficient of determination values $\left(R^{2}\right)$ value for each age group can also be developed. In female (pooled over age groups) simple regression model was developed using $\mathrm{WH} ; \mathrm{Y}=-237.347+$ $13.244^{*} \mathrm{WH}$ which has $93 \% \mathrm{R}^{2}$ value. Multiple regression model (including age as a factor) $\mathrm{Y}=-247.101+6.059 * \mathrm{WH}+0.032$ Age $+1.73 *$ HG show $96.1 \% \mathrm{R}^{2}$ value. In female (pooled over age groups) multiple regression was $\mathrm{Y}=-301.142+7.998 * \mathrm{WH}+$ 1.796* $\mathrm{HG}$ (when age not included as a factor in model) showed $94.4 \% \mathrm{R}^{2}$ value. Farmers can not accurately predict body weight of HF crossbred cattle visually.

\section{References}

Abdelhadi, O. M. A., and Babiker, S. A. (2012). Prediction of zebu cattle live weight using live animal measurements. Heart. 266 (38.6), 14-5.

Ahuja, L. D., Goswami, R. P., and Kuchhawah, S. S. (1965). Estimation of body weight of zebu cows from heart girth measurement. Annals of Arid Zone, 4, 17-23.

Alsiddig, M. A., Babiker, S. A., Galal, M. Y., and Mohammed, A. M. (2010). Phenotypic characterization of Sudan Zebu cattle (Baggara type). Research Journal of Animal and Veterinary Sciences, 5, 10-17.

Bahashwan, S. (2014). Application of morphometric traits for live body weight estimation in Dhofari calves. International Journal of Research in Agricultural Sciences, 1, 90-96.

Bhagat, V., Khune, V., Chourasia, S. K., Gendley, M. K., and Mukherjee, K. (2016). Linear regression equations for estimation of body weights in Sahiwal calves. Journal of Animal Research, 6 (2), 161.

Bhakat, M., Singh, C., and Chowdhry, N. R. (2008). Prediction of body weight on the basis of body measurements in Karan Fries cows and Murrah buffaloes. Indian Journal of Animal Research, 42 (2), 116-118.

Bozkurt, Y. (2006). Prediction of body weight from body size measurements in Brown Swiss feedlot cattle fed under smallscale farming conditions. Journal of Applied Animal Research, 29 (1), 2932.

Dhangar, M. R., and Patel, J. M. (1990). Prediction of body weight and gain in inter se mated Jersey $\times$ Kankrejhalfbred calves. Indian Journal of Animal Production and Management, 6 (2), 7072.

EL-Hedainy, D., Latif, M. G. A., and Mahdy, A. E. (2013). Prediction of Body Weight of Friesian Crossbred and Buffalo Male Calves during Fattening Using Live Body Measurements. Alexandria Journal of Agricultural Research, 58 (2), 159-163.

Goe, M. R., Alldredge, J. R., and Light, D. (2001). Use of heart girth to predict body weight of working oxen in the Ethiopian highlands. Livestock Production Science, 69 (2), 187-195.

Kanuya, N. L., Matiko, M. K., Nkya, R., Bittegeko, S. B., Mgasa, M. N., Reksen, O., and Ropstad, E. (2006). Seasonal changes in nutritional status and reproductive performance of Zebu cows kept under a traditional agro-pastoral system in Tanzania. Tropical Animal Health and Production, 38 (6), 511-519.

Kashoma, I., Luziga, C., Werema, C., Shirima, G., and Ndossi, D. (2011). Predicting body weight of Tanzania shorthorn zebu cattle using heart girth measurements. Livestock Research for 
Rural Development, 23 (4), 2011.

Katongole, C. B., Mpairwe, D., Bareeba, F. B., Mukasa-Mugerwa, E., and Ebong, C. (2013). Predicting body weight from heart girth, height at withers and body condition score in Bos indicus cattle bulls of Uganda. Livestock Research for Rural Development, 25 (3).

Milla, A. P., Mahagoub, M. M. M., and Bushara, I. (2012). Estimation of live body weight from heart girth, body length and condition score in Nilotic cattle-Southern Sudan. Journal of Animal Science and Biotechnology, 2 (5), 453-457.

Nesamvuni, A. E., Mulaudzi, J., Ramanyimi, N. D., and Taylor, G. J. (2000). Estimation of body weight in Ngunitype cattle under communal management conditions. South African Journal of Animal Science, 30 (1), 9798.

Nsoso, S. J., Aganga, A. A., Moganetsi, B. P., and Tshwenyane, S. O.(2003). Body weight, body condition score and heart girth in indigenous Tswana goats during the dry and wet seasons in southeast Botswana. Livestock Research for Rural Development, 15 (4).

Ozkaya, S., and Bozkurt, Y. (2009). The accuracy of prediction of body weight from body measurements in beef cattle. ArchivTierzucht, 52 (4), 371-377.

Paul, S. S., and Das, K. S. (2012). Prediction of Body Weight from Linear Body Measurements in Nili-Ravi Buffalo Calves. Journal of Buffalo Science, 1(1), 32-34.

Putra, W. P. B., Hartatik, T., Sumadi, S., andSaumar, H. (2014). Accuracy of heart girth for predicting live weight of Aceh cattle. Jurnallimu-Ilmu Peternakan, 24 (3), 45-53.

Roche, J. R., Lee, J. M., Macdonald, K. A., and Berry, D. P. (2007). Relationships among body condition score, body weight, and milk production variables in pasture-based dairy cows. Journal of Dairy Science, 90 (8), 3802-3815.

Sahu, S. S., Chaturvedani, A. K., Choursia, S. K., and Prakash, O. (2017). Correlation between body weight and linear body measurements in adult female Sahiwal cattle. The Indian Journal of Veterinary Sciences and Biotechnology, 12 (3), 9093.

Sawanon, S., Boonsaen, P., andInnuruk, P. (2011). Body measurements of male Kamphaengsaen beef cattle as parameters for estimation of live weight. Kasetsart Journal-Natural Science, 45, 428-434.

Serkan, O. and Yalcin, B.(2009). The accuracy of prediction of body weight from body measurements in beef cattle. Archiv Tierzucht, 52, 371-377.

Siddiqui, M. U., Lateef, M., Bashir, M. K., Bilal, M. Q., Muhammad, G., and Mustafa, M. I. (2015). Estimation of live weight using different body measurements in Sahiwal cattle. Pakistan Journal of Life \& Social Sciences, 13 (1).

Singh, M. K., Rai, B., Kumar, A., Sisodiya, H. S., and Singh, N. P. (2009). Production performance of Gohilwadi goats under range conditions. Indian Journal of Animal Sciences, 79 (6), 587-593.

Tanzania Society of Animal Production (1999). Body measurements as a management tool for crossbred dairy cattle at a smallholder farm condition. (Scientific Conference report of Tanzania Society of Animal Production). Tengeru, Tanzania: Msangi, B.S.J., Bryant, M.J., Kavana, Y., Msanga, N., Kizima, J.B.

Tasdemir, S., Urkmez, A., and Inal, S. (2011). Determination of body measurements on the Holstein cows using digital image analysis and estimation of live 
weight with regression analysis. Computers and Electronics in Agriculture, 76 (2), 189-197.

Tuzemen, N., Yanar, M., Akbulut, O., Ugur, F., and Aydin, R. (1995). Prediction of body weights from body measurements in Holstein-Friesian calves. Journal of Ataturk University Agriculture Faculty, $26,245-252$.

Ulutas, Z., Saatci, M., andOzluturk, A.
(2002). Prediction of body weights from body measurements in East Anatolian Red calves. Indian Journal of Animal Sciences, 72 (10), 878-881.

Yan, T., Mayne, C. S., Patterson, D. C., and Agnew, R. E. (2009). Prediction of body weight and empty body composition using body size measurements in lactating dairy cows. Livestock Science, 124 (1), 233-241.

\section{How to cite this article:}

Patel Ashwini, J., Patel Sanjay, G.J. Amipara, P.M. Lunagariya, D.J. Parmar and Rank, D.N. 2019. Prediction of Body Weight based on Body Measurements in Crossbred Cattle. Int.J.Curr.Microbiol.App.Sci. 8(03): 1597-1611. doi: https://doi.org/10.20546/ijcmas.2019.803.186 